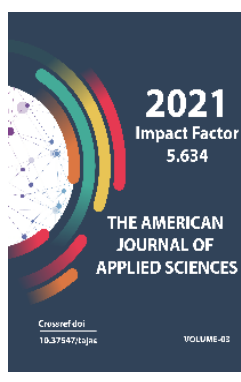

Journal Website: http://usajournalshub.c om/index,php/tajas

Copyright: Original content from this work may be used under the terms of the creative commons attributes 4.0 licence.

\section{The Medicinal Types Of Scutella (Lamiaceous) Group Spread Over Fergana Valley}

\author{
Muhayyo Xusanovna Akbarova \\ The Head Teacher, Fergana State University, Uzbekistan \\ Marhabo Foyzullayevna Bekchonova \\ Teacher, Fergana State University, Uzbekistan \\ Omina Muhammadzikirovna G'Ofurova \\ Teacher, Fergana State University, Uzbekistan \\ Tursunoy Erkinovna Usmanova \\ Master, Fergana State University, Uzbekistan
}

\title{
ABSTRACT
}

The article gives some information about the medicinal usage of scutella (lamiaceous) because of its biologically active substances in it, finding natural storage of the types, defining the modern condition of population, the necessity of saving endangered species.

\section{KEYWORDS}

Fergana valley, flora, province, flavonoid, glycoside, glycan, vitalitet, genofond, synopopulation, baykalin, baykalein, vogonin.

\section{INTRODUCTION}

In recent years, researches, which study biologically active substances, are being more in consideration. Take Scutella group as an example and over 65 types of their compositions were researched. Some substances like fenol carbon acid, fenilpropanoids, iridoit glycosides, deterpens, flavonoids, flacumin, rutin, likviriton, datiscan, flaming, silibor are widely used in medicine.

Scutellara $\mathrm{L}$ - al large polimorf group belongs to Lamiaceous. According to A. Paton, this group includes approximately more than 350425 types [1]. It is spread all over the world except The Arctic and Southern Africa, and 
The American Journal of Applied sciences

(ISSN - 2689-0992)

Published: April 29, 2021 | Pages: 105-110

have not found in desert or the bank of Amazon. The wide range of the types can be found in Irish-Turon province, mountainous areas of Central Asia, Yunnan and Sichuan provinces of China. (Abdullayeva, 1987; Paton, 1990).

Another necessity of observing Scutella L group is the noticeable increase of demand for observing Scultella $L$ in the flora of Uzbekistan. According to A.M Karimov (2007) and G'.U Siddiqov (2018), they got new flavonoids, glycosides, aglycones out of S.Sordifrons, S.phyllostachya, S.comosa, S.haematochlora, S.immaculata, Nevski, S. ocellata[1]. It is determined that such kind of substances can be equal to paratsetamol and geliotrin when it comes to cure inflammation and poisoning, balance blood pressure. On the other hand, with the help of these substances wool and woolen products can be dyed. Scientists get them from right nature when they producing such products. It is more preferable to prove the order of gaining Scutella, finding natural resources of them, estimating their future balance theoretically in order to save their genofond, to spread the types, to make charts representing its vitalitet, saving endangered species.

\section{THE AIM AND METHODS OF THE RESEARCH}

In this research in 2019-2020 some herbariums collected from all over the Fergana Valley, National herbarium of Uzbekistan, Moscow herbariums' centre, the herbarium centre of Samarkand state university in 1913-2020. The names of these types are taken from International Plants Names Index (www.ipni.org), the World plants Catalogue of Life (www.catalogueoflife.org) and "Authors of Plant Names" R.K. Brummit, C.E. Powell
(1992). In this research list of medicinal flora of Fergana valley is given and making this list Labitae in flora of Kyrgyzstan (2016) monografy, herbariums from all over the archives.

\section{DISCUSSIONS AND RESULT}

In our country some improvements are being done to discover new natural medicine instead of imported pills and supplying the public with high quality medicine products. For instance, observing the Scutella growing in Uzbekistan, getting flavonoids out of the plants.

According to researches, in a recent decade, the number of observations devoted to find new types, endemism, morphology, population, ontogenies of Scutella. They are more than other researches. More than 65 types were observed and more than 330 fenollike were taken. Some scientists like Y. Imoto, H.Kizu, T.Namba, N.Joshee, Y.Y. Zhang, C.R. Yang, Z.H. Zhoy, J. Miao, T. Tomimori, S.Shibata, Y. Kikuchi, Y. Miaichi, I.I. CHemesova, D.I. N.K.CHirikova, V.I.Litvinenko, T.P.Popova, M.linuma, A.L.Budansev and etc. researched in abroad. Baykalein, voganin and some other substances are used as antivirus, and cure for OITS and cancer. Some researcher are held in Uzbekistan too, like A.M Karimov (2017) and $G^{\prime}$.U. Siddiqovlar (2018). It is determined that such kind of substances can be equal to paratsetamol and geliotrin when it comes to cure inflammation and poisoning, balance blood pressure. Karimov (2017) and G'.U. Siddiqov (2018). 


\section{1- table. Scutella types spread over Fergana valley}

\begin{tabular}{|c|c|c|}
\hline № & Scutellaria turlari & Kimyoviy tarkibi \\
\hline 11. & $\begin{array}{c}\text { S. adenostegia } \\
\text { Briq. }\end{array}$ & $\begin{array}{l}\text { scutellarin , vogonin, oroksilin A (5,7-digidroksi, 6-metoksi flavon ), } \\
\text { Norvogonin (5,7,8- trigidroksi flavon), Kversetin (3,5,7, 3",4"-penta } \\
\text { gidroksiflavon), smola } 2.5 \% \text { gacha pirokatexin, guruhiga kiruvchi } \\
\text { oshlovchi moddalar va efir moyi, Flavon, Baykalein. }\end{array}$ \\
\hline 2. & S. comosa Juz. & apigenin, skutellarein, lyuteolin, gispidulin \\
\hline 3 & S. cordifrons Juz. & 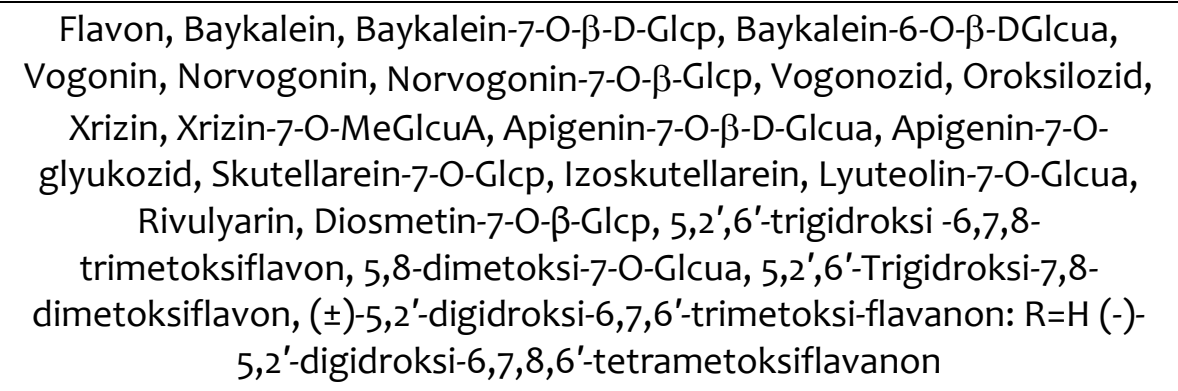 \\
\hline 4 & S. filicaulis Regel & apigenin, skutellarein, lyuteolin, gispidulin \\
\hline 5 & S. galericulata L. & $\begin{array}{l}\text { xrizin, 7-glyukuronid xrizin, baykalein, 7-glyukuronid baykalein, oroksilin, } \\
\text { oroksilozid, vogonin, vogonozid, skutellarin xrizin, apigenin, 7- } \\
\text { glyukuronid apigenin, lyuteolin, 7-glyukuronid lyuteolin, 6- } \\
\text { gidroksilyuteolin, 7-glyukuronid 6-gidroksilyuteolin, digidrobaykalein, 7- } \\
\text { glyukuronid digidrobaykalein, Efir moyi tarkibida kariofillen, trans-fi- } \\
\text { farnezen, menton, okten1-ol-Z, r-sabinen, a-gumulen, germatsen D, } \\
\text { limonen, baykalin, lyuteolin, skutellarin apigenin, skutellarein }\end{array}$ \\
\hline 6 & $\begin{array}{l}\text { S. haemato } \\
\text { chlora Juz. }\end{array}$ & 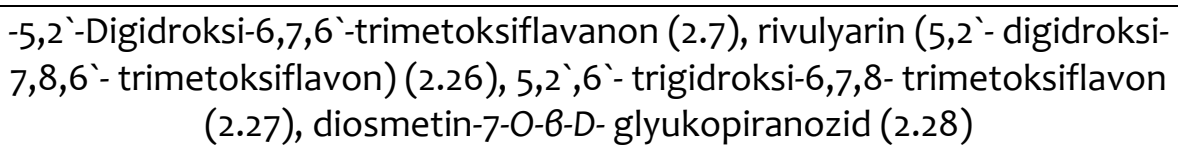 \\
\hline 7 & $\begin{array}{l}\text { S. immaculata } \\
\text { Nevski ex Juz. }\end{array}$ & 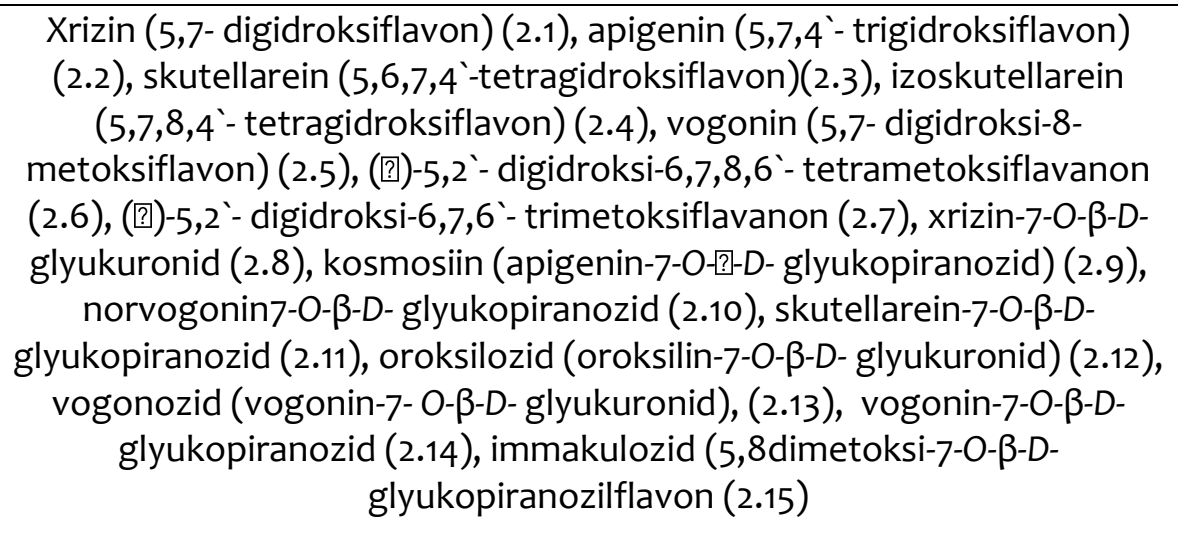 \\
\hline 8 & $\begin{array}{l}\text { S. intermedia } \\
\text { Popov }\end{array}$ & apigenin, skutellarein, lyuteolin, gispidulin \\
\hline
\end{tabular}




\begin{tabular}{|c|c|c|}
\hline 9 & S. ocellata Juz. & $\begin{array}{c}\text { apigenin, skutellarein, lyuteolin, gispidulin, Norvogonin }(5,7,8- \\
\text { trigidroksiflavon), Norvogonin } 7-0-\beta-D-\text { galakturonid - nepetozid A, } \\
\text { Norvogonin } 7-0-\beta-D \text { - glyukopiranozid }\end{array}$ \\
\hline 10 & S. oxystegia Juz. & Efir moylari $0.1 \%$. Alkaloidlar $0.21 \%$. Dubil moddalar $3.65 \%$ \\
\hline 11 & $\begin{array}{l}\text { S. pycnoclada } \\
\text { Juz. }\end{array}$ & apigenin, skutellarein, lyuteolin, gispidulin \\
\hline 12 & $\begin{array}{c}\text { S. ramosissima } \\
\text { Popov }\end{array}$ & apigenin, skutellarein, lyuteolin, gispidulin \\
\hline
\end{tabular}




\section{The map of spreading Scutella types in Fergana valley}
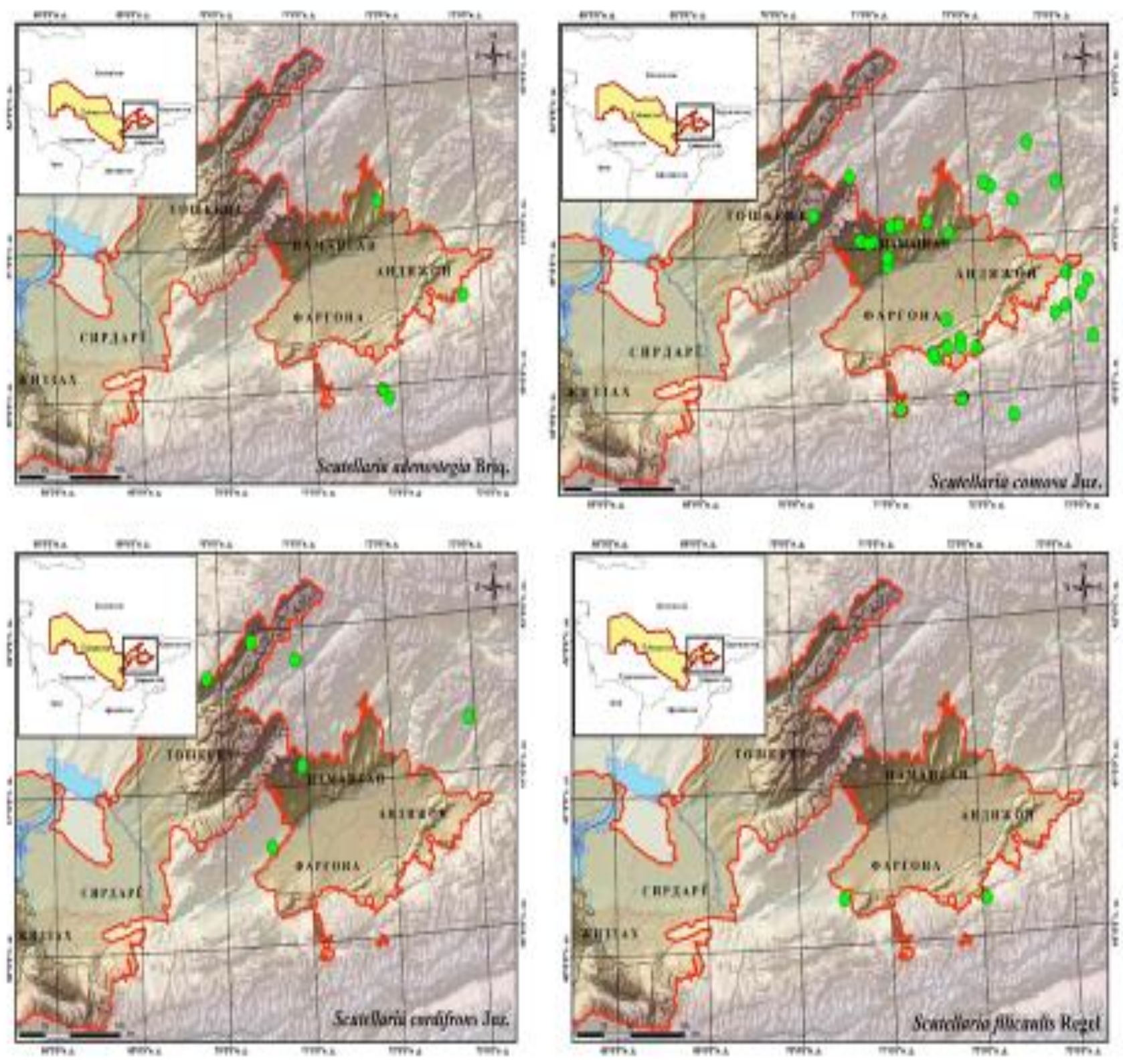

\section{REFERENCES}

1. Абдуллаева М.Н. (1987.) Род Scutellaria L. - Шлемник. Определитель растений Средней Азии. - Ташкент.: Фан, Т. IX. С. 13-37.

2. Akbarova M. X., Nabijonova G. F., Juraev Z. N. (2020). Distribution of Scutellaria adenostegia Briq. (Lamiaceae) in botanical and geographical regions of Uzbekistan // BBK 1 A28. - 2020. - C. 15. 
3. Акбарова, М. Х. Обидов МВ Dorivor Scutellaria comosa Juz.(Lamiaceae) Fargona vodiysidagi senopopulyatsiya holati. NamSU -Наманган-2020, 8, 78-87.

4. Акбарова, М.Х., Салимов, Н., Жураев, З., \& Набижонова, Г. (2020). ОЦЕНКА СОСТОЯНИЯ ЦЕНОТИЧЕСКИХ ПОПУЛЯЦИЙSCUTELLARIA COMOSA JUZ.(LAMIACEAE) ФЕРГАНСКОЙ ДОЛИНЫ. In Рациональное природопользование-основа устойчивого развития (рр. 12-17).

5. Акбарова, М. Х. (2020). Жураев ЗНУ Состояние ценопопуляций Scutellaria adenostegia Briq.(Lamiaceae) в Ферганской долине. Science and Education, 1, 4.

6. Акбарова, М. Х., Асадова, М. Қ., \& Жўраев, 3. H. Ў. (2021). SCUTELLARIA COMOSA JUZ.(LAMIACEAE) НИНГ ФАРҒОНА ВОДИЙСИДАГИ ТАБИИЙ ЗАХИРАЛАРИ. Academic research in educational sciences, 2(3).

7. floruz.uz [Электронный ресурс]. www.floruz.uz

8. Paton, A. (1990). A global taxonomic investigation of Scutellaria (Labiatae). Kew Bull. 45:399-450.

9. Ресурсоведение и стандартизация лекарственного растительного сырья: учеб. Пособие (2019). Сост.: К.А. Пупыкина, С.Р. Хасанова, Н.В. Кудашкина, Э.Х. Галиахметова, Р.Р. Шакирова. - Уфа: ФГБОУ ВО БГМУ Минздрава России, - 116 с.

10. Тургинов О.Т., Акбарова М.Х. (2020). Распространение видовой флоры рода Scutellaria L. (Lamiaceae) Ферганской долины // American Journal of Plant Sciences. - 2020. - T. 11. - C. 1533-1544.

11. Karimov A.M. Flavanoids of 4 plants that are the member of the Scutellaria L. specie growing in Uzbekistan: Dis. Cand. Biol of Sciences. - Tashkent: 2017.

12. Siddikov G.U. Second metabolits of plants S.Phyllostachya and S.Cordifrons, member of the species Scutellaria L. growing in Uzbekistan: separation, chemical structure and biological activity\&:Dis. Cand. Biol of Sciences. - Ferghana: 2018. 